\title{
Teaching and Research in Demography in Finland
}

\author{
By PAAVO PIEPPONEN \\ Institute of Sociology, University of Helsinki
}

\section{Higher Education}

In Finland, demography is not taught as a separate subject at universities. Yet demographic research has been carried out in the country for a long time. The very first Finnish doctoral dissertation which is demographic in subject matter was published in 1859. Nowadays, as well as earlier, demographic teaching at the academic level has been more individual in nature than formal lectures or seminars. At many institutes of social sciences, university teachers have promoted demographic research with the individual approach to demographic problems. During the past two years more formal lectures and seminars have been given at the University of Helsinki.

\section{University of Helsinki, Faculty of Social Sciences}

During September 1966 - May 1968 lectures and seminars on demographic and population problems have been given in connection with the teaching in sociology. Most of the participant students are aiming towards cum laude approbatur (middle degree) in sociology. Their main subject is sociology, social policy, economics, political science or psychology. The number of listeners has been $150-180$. At the end of each lecture series, an examination has been held. Those who have passed the examination have been released from one item in the requirements for middle degree in sociology.

The titles of the lecture series have been the following: in the autumn term 1966 and in the spring term 1968 "Introduction to demographic research". The main idea of the course has been to present the concepts and methods of demographic research at the elementary level. The course included a great deal of the content of the Multilingual Demographic Dictionary. Also some facts and relations with social phenomena have been discussed. In the spring term 1967 the title was "Population movements». In this course the problems of fertility, mortality, migration 
and marriage were touched upon from the methodological, numerical and sociological points of view. In the autumn term 1967 the course was given under the title "Population Development in Finland During the Last 50 Years». This course included structure and trend in population movements during the first 50 years of independent Finland.

A one semester seminar on "Population Problems» was arranged in the autumn term 1967. In this seminar population problems were studied and discussed from the global and national (Finnish) points of view. The students had to write reports on world population growth, natural resources, interrelations with economic and social factors, fertility, family planning, mortality, migration, population policy, etc. The seminar was one of the optional seminars necessary for the highest degree for a BA in sociology. The number of students was 29. Both lectures and seminars took 2 hours per week. Also in seminars where students' plans for their BA thesis are presented, several demographic topics have been discussed. Those students who have selected a demographic thesis have received individual orientation and also other participants have gained from this.

Besides sociology, demographic instruction has been arranged in social policy, economics and statistics in forms of seminars and informal guidance. Furthermore, students have to read demographic books and studies for degrees in sociology, social policy, economics and statistics. Sometimes it is optional, sometimes a book or two is compulsory. For example, in sociology, the reading list in demography for the most advanced students consists of 650 pages. In statistics it is also possible to choose the demographic (demometric) section.

\section{University of Tampere}

Each semester a course in demographic methods is held by the chief of the Tampere City Statistical Office. This course is open to all students of the University. It is held two hours per week. Otherwise the situation is similar that in the University of Helsinki. Institutes of social policy, sociology, economics and social ecology give individual instruction to students who have selected a demographic thesis.

University of Turku and Abo Akademi (Swedish University in Turku) also give instruction in demography.

\section{Research}

A. Government and municipal institutions

1. Division of Population Statistics, Central Statistical Office of Finland, Chief of the Division Mr. Jorma Hyppölä, Helsinki. 
This Division is mostly a data collecting and publishing bureau but there is one person engaged in demographic research. Part of his duties is to prepare population projections for the whole country. The results of the investigations are published in the publications of the Central Statistical Office or elsewhere.

2. The Statistical Office of the City of Helsinki. Chief: Mr K-E. Forsberg, Helsinki.

This institution is also mostly a data-collecting bureau. There are $2-3$ persons who have carried out demographic research. Research reports are published in the institution's own series.

3. Labour Research Bureau, Chief: Mrs Toini Ristimäki.

This is a government institution. The main function is to prepare statistics on labour force. For this purpose it collects material several times a year from samples. They carry out applied research primarily.

4. National Planning Office, Helsinki. Chief: Mr Väinö Paavilainen. This institution employs one demographer.

5. Research Division at the National Pension Institute, Helsinki. Chief: Dr Tapani Purola. The main function of the Research Division is to study the morbidity and social security of old people. It has published an extensive sample survey on morbidity and on the use of medical services before the establishment of national health insurance. It has also collected material for continued studies on this topic.

\section{B. University Institutions}

1. Institute of Sociology, University of Helsinki. Head: Prof. Erik Allardt.

2. Institute of Social Policy, University of Helsinki. Head: Prof. Olavi Riihinen.

These institutions sometimes carry out demographic research. Studies and reports prepared by the students are not usually published. However, they are available in the faculty library.

\section{Private Institutions}

1. Population Research Institute, Helsinki. Head: Prof. V. J. Sukselainen.

This institute is a research department of the Finnish Family and Welfare League. It was founded as early as in 1946, but has remained a small institution. Now it has three researchers and two office clerks. Demographic research is but one area. It also publishes a yearbook in which persons outside of the institute have the possibility of getting their studies published. 


\section{Teaching on a non-academic level}

\section{University of Tampere}

The University of Tampere also has a non-academic section with the aim of training social workers. One position there, the lecturer in labour force, is relevant here. His duty is give courses in labour force policy, problems of labour force and vocational guidance, and direct seminars. His teaching duty is 8 hours per week.

\section{School of Nursing in Helsinki}

In this non-academic school the material taught under Family Sociology include family and fertility problems. The whole course is only 8 hours. The students are nurses who specialise in public health, social work, etc.

\section{Discussion}

The ensuing discussion had the following speakers: Fougstedt, Gille, Hoem, Hofsten, Hyrenius, Kongstad, Majava, Matthiessen and $\emptyset$ yen.

It was established that demography is gaining ground, but that we in the Scandinavian countries have not kept pace with the development in other countries. We need professors in demography in Scandinavia.

On the one hand, it was felt that no distinction should be drawn between formal demography and applied demography. On the other hand, it was pointed out that it is important to separate demography from other disciplines. Furthermore, it was emphasised that teaching should take a practical direction, and that Scandinavia should take part in the training of demographers for the developing countries, where such a need is great.

As far as the teaching itself is concerned, it was reported that in Finland oneterm studies were contemplated, although it was thought that one term was perhaps too brief. Nevertheless, it was stressed that at least fundamental teaching should be given to students of different disciplines. Perhaps the summer universities should incorporate the teaching of demography in their programmes.

During the discussion, warning voices were raised against mixing too many disciplines in a teaching system of demography.

Further discussion was concerned with the way in which the teaching should be given, at a central institute, or decentralised. No concrete proposal was put forward, but it was stated that consideration should be paid to the need, and the different auxiliary sciences made resort to in demography.

The symposium returned to this question on Thursday, in conjunction with the forms of demographic cooperation in Scandinavia.

NOTE. Prof. Carl-Erik Quensel, and Mr Jan M Hoem presented a report related to teaching and research in demography in Sweden and Norway respectively.

A later version of $\mathrm{Mr}$ Hoem's paper will appear in a report prepared by Professor D. V. Glass for UNESCO and the International Union for the Scientific Study of Population. 